GRASAS Y ACEITES 65 (2)

April-June 2014, e016

ISSN-L: 0017-3495

doi: http://dx.doi.org/10.3989/gya.086513

\title{
Synthesis and antioxidant activity of two novel tetraphenolic compounds derived from toluhydroquinone and tertiary butylhydroquinone
}

\author{
Z.W. Jiang, X.C. Weng ${ }^{\bowtie}$, Y. Huang, J.P. Hou and X.Y. Liao \\ School of Life Sciences, Shanghai University, Shanghai 200444, China \\ Corresponding author:wxch@staff.shu.edu.cn
}

Submitted: 22 August 2013; Accepted: 10 December 2013

SUMMARY: Two novel compounds bearing four hydroxyphenyl groups were synthesized by the acid-catalyzed condensation reaction of glyoxal with toluhydroquinone (THQ) or tertiary butylhydroquinone (TBHQ), respectively. The antioxidant activity of the newly synthesized compounds was assessed by the Rancimat test, a 2,2-diphenyl 1-picrylhydrazyl (DPPH) assay and reducing power assay. In the Rancimat antioxidant test using lard oil as substrate, the performance of two newly synthesized compounds was superior to TBHQ at $140{ }^{\circ} \mathrm{C}$. It was suggested that two newly synthesized compounds can be used to improve the oxidative stability of lipid products during high temperature processing. With regard to the DPPH radical scavenging activity and reducing power, the performance of synthesized compounds was inferior to their mother compounds, respectively. The results show that the DPPH radical scavenging activity and reducing power of a compound did not correlate with its ability to retard lipid oxidation.

KEYWORDS: Antioxidant activity; Condensation reaction; DPPH; TBHQ; THQ

RESUMEN: Síntesis y actividad antioxidante de dos nuevos compuestos tetrafenólicos derivados de toluhidroquinona y terbutilhidroquinona. Dos nuevos compuestos con cuatro grupos hidroxifenilo se sintetizaron mediante reacción de condensación catalizada por glioxal con toluhidroquinona (THQ) o terbutilhidroquinona (TBHQ), respectivamente. La actividad antioxidante de los compuestos sintetizados se evaluó mediante Rancimat, método del 2,2-difenil-1-picrilhidrazil (DPPH) y poder reductor. Para el ensayo de Rancimat se usó manteca de cerdo como sustrato, la efectividad de los dos compuestos recién sintetizados fue superior a la del TBHQ a $140{ }^{\circ} \mathrm{C}$. Se sugiere que los compuestos sintetizados se pueden utilizar para mejorar la estabilidad oxidativa de productos lipídicos durante el procesamiento a alta temperatura. Con respecto a la actividad de eliminación de radicales DPPH y poder reductor, la efectividad de los compuestos sintetizados fue inferior a los compuestos matrices. Los resultados mostraron que la actividad de eliminación de radicales DPPH y poder reductor de un compuesto no se correlacionó con su capacidad para retardar la oxidación lipídica.

PALABRAS CLAVE: Actividad antioxidante; DPPH; Reacción de condensación; TBHQ; THQ

Citation/Cómo citar este artículo: Jiang ZW, Weng XC, Huang Y, Hou JP. Liao XY. 2014. Synthesis and antioxidant activity of two novel tetraphenolic compounds derived from toluhydroquinone and tertiary butylhydroquinone. Grasas Aceites 65 (2): e016. doi: http://dx.doi.org/10.3989/gya.086513.

Copyright: (C) 2014 CSIC. This is an open-access article distributed under the terms of the Creative Commons Attribution-Non Commercial (by-nc) Spain 3.0 Licence. 


\section{INTRODUCTION}

Food lipids are very susceptible to oxidative processes in the presence of catalytic systems such as light, heat, enzymes, metals, and metalloproteins, resulting in adverse changes in sensory quality, nutritional value and chemical composition (Shahidi and Zhong, 2010). The addition of synthetic antioxidants is the most convenient and effective way to retard lipid oxidation and thus prevent food deterioration. Tertiary butylhydroquinone (TBHQ) and some sterically hindered phenolics are very effective primary antioxidants at room or moderate temperatures and widely used in the food industry. However, these low molecular weight antioxidants tend to lose their effectiveness during hightemperature food processing like deep frying and baking, because of chemical degradation, volatilization and steam distillation (Hamama and Nawar, 1991; Marmesat et al., 2010). Thus, relatively high molecular weight antioxidants are preferably used to overcome physical loss and to enhance thermal stability under high temperatures. Novel antioxidants derived from TBHQ, i.e., lauryl TBHQ, lauryl tert-butylated quinone and 1,1-di-(2',5'-dihydroxy4'-tertbutylphenyl)ethane, have been found to exert stronger antioxidant activity than TBHQ at temperatures higher than $140{ }^{\circ} \mathrm{C}$ (Zhang et al., 2004; Li et al., 2006). In this paper, two novel tetraphenolic compounds were prepared by the acid-catalyzed condensation reaction of glyoxal with toluhydroquinone (THQ) or TBHQ, respectively. The antioxidant properties of these compounds were also studied.

\section{MATERIALS AND METHODS}

\subsection{Materials and chemicals}

THQ and 2,2-diphenyl-1-picrylhydrazyl (DPPH) were purchased from Sigma-Aldrich Co. TBHQ, silica gel and other chemicals were purchased from Shanghai Chemical Reagent Co. All chemicals were of analytical grade and used without further purification. Thin-layer chromatographic (TLC) plates were prepared by coating $0.5 \mathrm{~mm}$ silica gel F254 onto $2.5 \times 7.5 \mathrm{~cm}$ glass plates and then activated by heating in an oven for thirty minutes at $110{ }^{\circ} \mathrm{C}$.

\subsection{Preparation of compound 1}

A mixture of THQ (12.41 g, $0.10 \mathrm{~mol})$, glyoxal $(40 \%, 1.20 \mathrm{~mL}, 0.01 \mathrm{~mol})$, phosphoric acid $(85 \%$, $0.68 \mathrm{~mL}, 0.01 \mathrm{~mol})$ and isopropanol $(25 \mathrm{~mL})$ was stirred and heated to reflux. Nitrogen was bubbled to remove the air in the reaction system during refluxing. After $24 \mathrm{~h}$ of reaction, the mixture was evaporated under vacuum and the residue was washed with hot water $(250 \mathrm{~mL} \times 3)$ followed by an ethyl acetate/n-hexane mixture $(1: 1,25 \mathrm{~mL})$. The pure product was obtained by recrystallization from ethanol and dried under vacuum.

\subsection{Preparation of compound 2}

A mixture of TBHQ (16.62 g, $0.10 \mathrm{~mol})$, glyoxal $(40 \%, 1.20 \mathrm{~mL}, 0.01 \mathrm{~mol})$, phosphoric acid $(85 \%$, $0.68 \mathrm{~mL}, 0.01 \mathrm{~mol})$ and isopropanol $(25 \mathrm{~mL})$ was stirred and heated to reflux. Nitrogen was bubbled to remove any air in the reaction system during refluxing. After $24 \mathrm{~h}$ of reaction, the mixture was evaporated under vacuum and the residue was washed with boiling water $(250 \mathrm{~mL} \times 3)$ followed by chloroform $(25 \mathrm{~mL})$. The pure product was obtained by recrystallization from ethanol and dried under vacuum.

\subsection{Analytical determination for the characterization of the compounds}

${ }^{1} \mathrm{H}$ and ${ }^{13} \mathrm{C}$ NMR spectra were recorded with a Bruker AVANCE $500 \mathrm{MHz}$ spectrometer; chemical shifts were reported in ppm using TMS as internal standard. IR spectra were recorded on Nicolet FT-IR spectrometer. UV spectra were recorded with a Varian Cary 100 Bio UV-Vis spectrophotometer. Fluorescence spectra were recorded with a Perkin-Elmer LS55 luminescence spectrometer. High-resolution ESI mass spectrometry was performed with Bruker APEXIII 7.0 TESLA FTMS. Analytical TLC was performed on $0.25 \mathrm{~mm}$ precoated silica gel plates.

\subsection{Rancimat test}

The antioxidant activities of THQ, TBHQ and two newly synthesized compounds were measured according to a published method (Proestos et al., 2006). Samples of lard oil ( $3 \mathrm{~g})$ containing $0.02 \%$ compounds were subjected to oxidation. The air flow rate was fixed at $20 \mathrm{~L} / \mathrm{h}$, and the temperature was controlled at 100,120 and $140{ }^{\circ} \mathrm{C}$, respectively. Induction periods (IP), the period of time until a sudden acceleration of the oxidative process is reached (Silva et al., 2001), were recorded automatically. The IP of lard oil containing different concentrations $(0.01 \%, 0.02 \%, 0.04 \%$ and $0.08 \%)$ of compounds 1 and 2 were also determined at $120^{\circ} \mathrm{C}$, while the air flow was kept at $20 \mathrm{~L} / \mathrm{h}$. The protection factors (PF) were calculated according to the following formula:

\section{$\mathrm{PF}=\mathrm{IP}$ sample/IP control.}

The lard oil without the addition of antioxidant served as the control. The lard oil applied in this method was rendered in the laboratory from fresh pig fat tissue. 


\subsection{DPPH radical scavenging assay}

The free radical scavenging activities of the compounds were assayed according to the previously reported method with some modification (Shimada, et al., 1992; Tseng, et al., 2008). Aliquots of $0.5 \mathrm{~mL}$ of sample solution of different concentrations (1.5 to $\left.48 \mu \mathrm{g} \cdot \mathrm{mL}^{-1}\right)$ in ethanol was mixed with $2.5 \mathrm{~mL}$ of DPPH $(0.1 \mathrm{mM}$ in ethanol). The mixture was shaken vigorously and left to stand for $30 \mathrm{~min}$ in the dark, and the absorbance was then measured at 517 $\mathrm{nm}$ against a blank. The antioxidant activity was calculated using the following equation:

\section{Scavenging activity $(\%)=[\Delta \mathrm{A} 517$ of control-} $\Delta \mathrm{A} 517$ of sample) $/ \Delta \mathrm{A} 517$ of control] $\times 100$.

$\mathrm{EC}_{50}$ is defined as the concentration of substrate that causes a $50 \%$ loss in the DPPH activity (Molyneux, 2004). It is calculated from the graph plotted as scavenging activity against compound concentration.

\subsection{Reducing power}

The reducing power of each compound was determined according to the method of Oyaizu (1986). Briefly, $1.0 \mathrm{~mL}$ of different sample concentrations $\left(1.5-48 \mu \mathrm{g} \cdot \mathrm{mL}^{-1}\right)$ was mixed with $2.5 \mathrm{~mL}$ of a $0.2 \mathrm{M}$ phosphate buffer ( $\mathrm{pH} 6.6$ ) and $2.5 \mathrm{~mL}$ of a $1 \%(\mathrm{w} / \mathrm{v})$ solution of potassium ferricyanide. The mixture was incubated at $50{ }^{\circ} \mathrm{C}$ for $20 \mathrm{~min}$. After that, $2.5 \mathrm{~mL}$ of $10 \%(\mathrm{w} / \mathrm{v})$ trichloroacetic acid were added, and the mixture was centrifuged at $3000 \mathrm{rpm}$ for $10 \mathrm{~min}$. A $2.5 \mathrm{~mL}$ aliquot of the upper layer was combined with $2.5 \mathrm{~mL}$ of distilled water and $0.5 \mathrm{~mL}$ of $0.1 \%(\mathrm{w} / \mathrm{v})$ ferric chloride, and the absorbance was measured at $700 \mathrm{~nm}$ against a blank. A higher absorbance indicates a higher reducing power. The $\mathrm{EC}_{50}$ value is the effective concentration at which the absorbance was 0.5 for reducing power and was obtained by interpolation from linear regression analysis.

\subsection{Statistical analysis}

The results were presented as mean \pm standard error of the mean. Statistical comparisons were made using SPSS version 16.0 for Windows. Oneway analysis of variance (ANOVA) was used to identify significant differences $(\mathrm{P} \leq 0.05)$.

\section{RESULTS AND DISCUSSION}

\subsection{Characterization of compound 1 and 2}

Compounds 1 and 2 were obtained as white flocculent crystals. $R_{\mathrm{f}}$ values of compound 1 and 2 were 0.45 and 0.58 respectively (Chloroform/ethanol, 9:1). Their UV spectra were very similar showing two broad absorption bands in the range of $200-$ $330 \mathrm{~nm}$. A strong fluorescence peak of compounds 1 and 2 , located at $\lambda \mathrm{ex} / \lambda \mathrm{em}=332.1 / 344.16 \mathrm{~nm}$ and $331.57 / 343.96 \mathrm{~nm}$ respectively, were observed in the fluorescence spectrum. With regard to compound 1 , its IR spectra showed bands for hydroxyl groups $\left(3509 \mathrm{~cm}^{-1}\right)$ and aromatic rings $\left(1508,1461 \mathrm{~cm}^{-1}\right)$. The ${ }^{1} \mathrm{H}$ NMR spectrum of compound 1 exhibited a phenolic hydroxyl proton signal at $7.744 \mathrm{ppm}$, two aromatic proton signals at 6.590 and $6.895 \mathrm{ppm}$, two doublets of proton signals with a vicinal coupling constant of $6.5 \mathrm{~Hz}$ at 4.929 and $6.785 \mathrm{ppm}$, and a methyl proton signal at $2.125 \mathrm{ppm}$. The ${ }^{13} \mathrm{C}$ NMR spectrum of compound 1 exhibited 9 carbon signals, including six aromatic carbon signals, a methyl carbon signal and two methine signals. From the NMR data, it could be deduced that the molecular formula of compound 1 is $\mathrm{C}_{32} \mathrm{H}_{28} \mathrm{O}_{8}$. Since its HRMS also showed $[\mathrm{M}+\mathrm{Na}]^{+}$at $\mathrm{m} / \mathrm{z} 563.1664$ (calcd. for $\mathrm{C}_{32} \mathrm{H}_{28} \mathrm{Na}_{1} \mathrm{O}_{8}$ 563.1676), its structure was further confirmed. The IR, ${ }^{1} \mathrm{H}$ NMR and ${ }^{13} \mathrm{C}$ NMR spectrum characters of compound 2 were very similar to those of compound 1 as shown in Table 1, except for the difference caused by tert-butyl substituents. The HRMS data of compound 2 (calcd. for $\mathrm{C}_{44} \mathrm{H}_{52} \mathrm{Na}_{1} \mathrm{O}_{8}[\mathrm{M}+\mathrm{Na}]^{+}$731.3554, found 731.3558) was also in good agreement with its NMR result.

TABLE 1. Spectroscopic data of Compound 1 and Compound 2

\begin{tabular}{|c|c|c|c|c|c|}
\hline & $\begin{array}{c}{ }^{1} \mathrm{H} \text { NMR } \\
\text { (Acetone- } d_{6}, 500 \mathrm{MHz} \text { ) } \\
\end{array}$ & $\begin{array}{c}{ }^{13} \mathrm{C} \text { NMR } \\
\text { (Acetone- } d_{6}, 500 \mathrm{MHz} \text { ) }\end{array}$ & $\begin{array}{c}\mathrm{IR} \\
\left(\mathrm{KBr}, v / \mathrm{cm}^{-1}\right) \\
\end{array}$ & $\begin{array}{c}\text { UV (Methanol, } \\
\lambda / \mathbf{n m})\end{array}$ & $\begin{array}{c}\text { HRMS } \\
{[\mathrm{M}+\mathrm{Na}]^{+}}\end{array}$ \\
\hline Compound 1 & $\begin{array}{l}2.125\left(\mathrm{~s}, 12 \mathrm{H}, \mathrm{CH}_{3}\right) \\
4.929(\mathrm{~d}, 2 \mathrm{H}, J=7.0 \mathrm{~Hz}, \mathrm{CH}) \\
6.590,6.895(\mathrm{~s}, 8 \mathrm{H}, \text { arom } \mathrm{CH}) \\
6.785(\mathrm{~d}, 2 \mathrm{H}, J=6.5 \mathrm{~Hz}, \mathrm{CH}) \\
7.744(\mathrm{~s}, 4 \mathrm{H}, \mathrm{OH})\end{array}$ & $\begin{array}{l}16.990\left(\mathrm{CH}_{3}\right) \\
51.936(\mathrm{CH}) \\
111.795,112.444,125.691,126.969, \\
151.318,152.322(\text { arom } \mathrm{CH}) \\
114.411(\mathrm{CH})\end{array}$ & $\begin{array}{l}3509,2980 \\
2964,2908 \\
2860,1508 \\
1461,1418 \\
1201,1174 \\
966,766\end{array}$ & 215,306 & 563.1664 \\
\hline Compound 2 & $\begin{array}{l}1.343\left(\mathrm{~s}, 36 \mathrm{H}, \mathrm{CH}_{3}\right) \\
4.946(\mathrm{~d}, 2 \mathrm{H}, J=6.5 \mathrm{~Hz}, \mathrm{CH}) \\
6.710,6.882(\mathrm{~s}, 8 \mathrm{H}, \text { arom } \mathrm{CH}) \\
6.804(\mathrm{~d}, 2 \mathrm{H}, J=6.5 \mathrm{~Hz}, \mathrm{CH}) \\
7.966(\mathrm{~s}, 4 \mathrm{H}, \mathrm{OH})\end{array}$ & $\begin{array}{l}30.181\left(\mathrm{CH}_{3}\right) \\
35.772(\mathrm{C}) \\
51.890(\mathrm{CH}) \\
108.869,112.981,126.534,137.503, \\
151.821,152.468(\text { arom } \mathrm{CH}) \\
114.356(\mathrm{CH})\end{array}$ & $\begin{array}{l}3431,3381 \\
2960,2918 \\
2871,2848 \\
1500,1425 \\
1198,1172 \\
986,867,776\end{array}$ & 213,309 & 731.3558 \\
\hline
\end{tabular}


TABLE 2. IP and PF changes in lard samples containing $0.02 \%(\mathrm{w} / \mathrm{w})$ antioxidants at different temperatures

\begin{tabular}{|c|c|c|c|c|c|c|}
\hline & \multicolumn{2}{|c|}{$100^{\circ} \mathrm{C}$} & \multicolumn{2}{|c|}{$120^{\circ} \mathrm{C}$} & \multicolumn{2}{|c|}{$140^{\circ} \mathrm{C}$} \\
\hline & IP & PF & IP & PF & IP & PF \\
\hline Control & $8.60 \pm 0.04^{\mathrm{e}}$ & 1.00 & $1.65 \pm 0.03^{\mathrm{d}}$ & 1.00 & $0.34 \pm 0.01^{\mathrm{e}}$ & 1.00 \\
\hline THQ & $30.23 \pm 0.80^{\mathrm{d}}$ & 3.52 & $6.88 \pm 0.32^{\mathrm{c}}$ & 4.16 & $1.66 \pm 0.09^{\mathrm{d}}$ & 4.96 \\
\hline Compound 1 & $44.64 \pm 1.18^{\mathrm{c}}$ & 5.19 & $10.11 \pm 0.18^{\mathrm{b}}$ & 6.12 & $2.70 \pm 0.13^{\mathrm{b}}$ & 8.05 \\
\hline TBHQ & $51.37 \pm 0.90^{\mathrm{b}}$ & 5.98 & $10.51 \pm 0.52^{\mathrm{b}}$ & 6.36 & $2.38 \pm 0.04^{\mathrm{c}}$ & 7.10 \\
\hline Compound 2 & $55.27 \pm 1.35^{\mathrm{a}}$ & 6.43 & $12.03 \pm 0.28^{\mathrm{a}}$ & 7.28 & $3.20 \pm 0.04^{\mathrm{a}}$ & 9.54 \\
\hline Sig. & $* *$ & & $* *$ & & $* *$ & \\
\hline
\end{tabular}

IP are expressed as mean \pm standard deviation $(n=4)$. PF are calculated using the mean value of IP. Data followed by different letters are significantly different according to Duncan's multiple range test. *Significance at $\mathrm{P} \leq 0.05,{ }^{* *}$ Significance at $\mathrm{P} \leq 0.01$, n.s. not significant.

Based on the above evidence, compounds 1 and 2 were determined to be two novel tetraphenolic compounds bearing four hydroxyphenyl groups.

Tetraphenolic compounds are important chemical products which can be used as starting materials for the preparation of multifunctional epoxy resins for coatings and electronic applications (Bauer and Dangayach, 1992; Li, 1992). The condensation reaction of glyoxal with a phenol or alkylphenol is a conventional method for preparing tetraphenolic compounds. In our study, novel compounds containing eight phenolic hydroxyl groups were expected to be prepared from the condensation reaction of glyoxal with a molar excess of alkyl-substituted hydroquinone by analogy. But it turned out that the intermediate was unable to react further with THQ or TBHQ due to steric hindrance, and an acetylation reaction occurred between two intermediate molecules as shown in Scheme 1. It can be inferred that the hydroxyl groups at the meta-position of the methyl or tertiary butyl substituent acted as a nucleophile, which attacked the positively charged carbon of carbonyl groups and pushed one of the double bond electrons onto oxygen to give it a negative charge. Then the negatively charged oxygen attacked the proton $\left(\mathrm{H}^{+}\right)$to form a hemiacetal. Since the hemiacetal was unstable, it was accessible to react further to form acetal. As a result, compounds 1 and 2 were finally isolated. The percent yield was about $10 \%$, which was calculated by the isolated yield divided by the theoretical yield. The reaction of glyoxal with alkyl-substituted hydroquinones provided a new approach to the synthesis of tetraphenolic compounds.

\subsection{Antioxidant activity in Rancimat test}

The effect of antioxidants on the oxidative stability of lard oil was evaluated by PF. As shown in Table 2, there was a good positive correlation between the PF of samples and temperatures. It indicated that the oxidative stability of lard oil was more sensitive to antioxidants at higher temperatures because of accelerated lipid oxidation. With regard to the protection against lipid oxidation, the performance of compounds decreased as follows: compound $2>$ TBHQ $>$ compound $1>$ THQ (100 and $120{ }^{\circ} \mathrm{C}$ ). When the temperature was controlled at $140^{\circ} \mathrm{C}$, the performance of both compounds 1 and 2 (PF of 8.05 and 9.54, respectively) were superior to that of TBHQ with $7.10(\mathrm{P} \leq 0.01)$. The results revealed that polyphenols with a relatively higher molecular weight are preferably used to delay lipid oxidation during the high temperature processing of fats and oils. The effectiveness of THQ and TBHQ was relatively low, which could be attributed to their partial decomposition or volatilization. Table 3 shows the increase in PF with increasing concentrations of compounds 1 and 2, from 5.20

TABLE 3. IP and PF changes in lard samples containing different concentrations of compounds 1 and 2 at $120^{\circ} \mathrm{C}$

\begin{tabular}{|c|c|c|c|c|c|c|c|c|}
\hline & \multicolumn{2}{|c|}{$0.01 \%$} & \multicolumn{2}{|c|}{$0.02 \%$} & \multicolumn{2}{|c|}{$0.04 \%$} & \multicolumn{2}{|c|}{$0.08 \%$} \\
\hline & IP & PF & IP & PF & IP & PF & IP & PF \\
\hline Compound 1 & $8.58 \pm 0.13^{b}$ & 5.20 & $10.11 \pm 0.18^{b}$ & 6.12 & $11.89 \pm 0.68^{b}$ & 7.19 & $13.02 \pm 0.81^{\mathrm{b}}$ & 7.88 \\
\hline Compound 2 & $9.70 \pm 0.15^{\mathrm{a}}$ & 5.87 & $12.03 \pm 0.28^{\mathrm{a}}$ & 7.28 & $14.63 \pm 0.86^{\mathrm{a}}$ & 8.85 & $16.41 \pm 0.16^{\mathrm{a}}$ & 9.93 \\
\hline Sig. & $* *$ & & $* *$ & & $* *$ & & $* *$ & \\
\hline
\end{tabular}

IP are expressed as mean \pm standard deviation $(n=4)$. PF are calculated using the mean value of IP. Data followed by different letters are significantly different according to independent sample t-tests. *Significance at $\mathrm{P} \leq 0.05,{ }^{* *}$ Significance at $\mathrm{P} \leq 0.01$, n.s. not significant. 


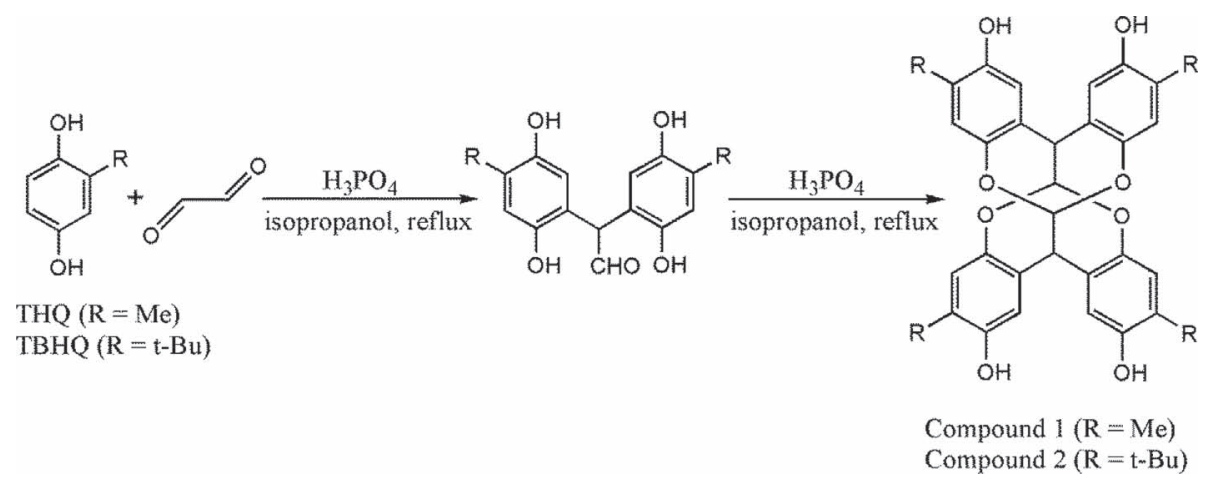

SCHEme 1. Synthesis of two novel tetraphenolic compounds derived from THQ and TBHQ.

to 7.88 and from 5.87 to 9.93 , respectively $\left(120^{\circ} \mathrm{C}\right)$. Compound 2 exhibited stronger antioxidant activity than compound $1 \quad(\mathrm{P} \leq 0.01)$. We inferred that bulky tert-butyl substituents in the position ortho of phenolic hydroxyl groups enhanced the stability of phenoxy radicals and thus increased the oxidative stability of lard oil. Although compounds 1 and 2 exhibited stronger antioxidant activity, it would be difficult for them to be declared legal for use as food additives. Therefore, we intend to investigate their toxicological properties in the next stage, including acute oral toxicity in rats, sub-acute oral toxicity in rats and intra-peritoneal toxicity in mice.

\subsection{DPPH radical scavenging activity}

The scavenging activity of antioxidants on DPPH radicals rapidly increased from 1.5 to 12 $\mu \mathrm{g} / \mathrm{mL}$ (Figure 1). At $12 \mu \mathrm{g} \cdot \mathrm{mL}^{-1}$, the scavenging activities were $54.2 \%, 37.3 \% 27.1 \%$ and $10.8 \%$ for THQ, TBHQ, compound 1 and 2, respectively. The $\mathrm{EC}_{50}$ of THQ, TBHQ, and compounds 1 and 2 were $12.43,15.32,31.64$ and $106.95 \mu \mathrm{g} \cdot \mathrm{mL}^{-1}$, respectively.

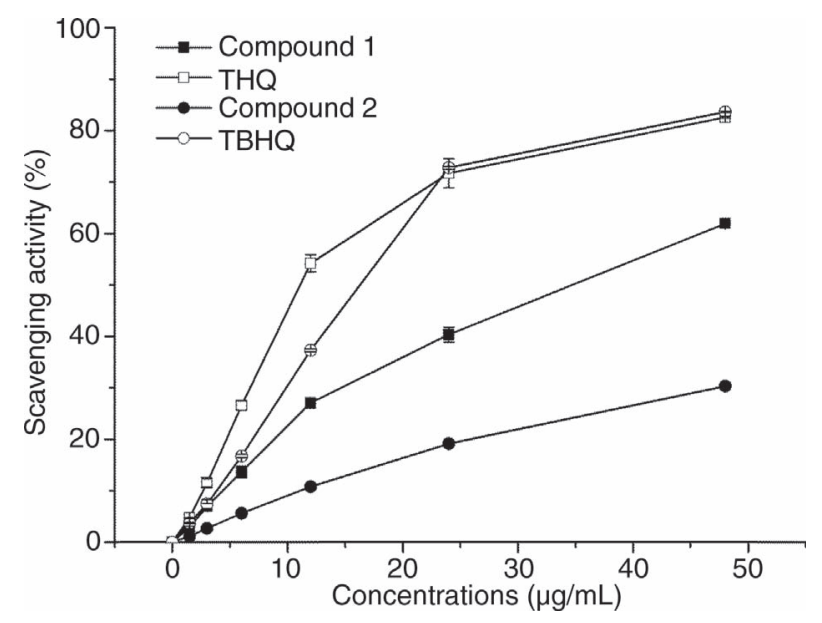

FIGURE 1. DPPH free radical scavenging activity of different antioxidants. Each value is expressed as mean \pm standard deviation $(n=3)$.
In conclusion, the DPPH radical scavenging activity of these compounds followed the following order: THQ $>$ TBHQ $>$ compound $1>$ compound 2 . The order was opposite to the results of the Rancimat test indicating that the DPPH radical scavenging activity of a compound did not correlate with its ability to inhibit lipid oxidation. There are three main reasons for this: firstly, with the same mass percentage concentration, the phenolic hydroxyl group content in the samples of compounds 1 and 2 is less than half that of THQ and TBHQ, respectively. Secondly, DPPH radicals are long-lived nitrogen radicals that are artificially generated and bear no similarity to the highly reactive and transient peroxyl radicals which are involved in lipid oxidation (Huang et al., 2005). Therefore, compounds 1 and 2 may react slowly with DPPH, although they could react rapidly with peroxyl radicals. Thirdly, alkyl substituents also exert an influence on the DPPH radical scavenging activity of the compounds. As a result, the assay has some limitations for evaluating the antioxidant activity of polyphenols in food systems.

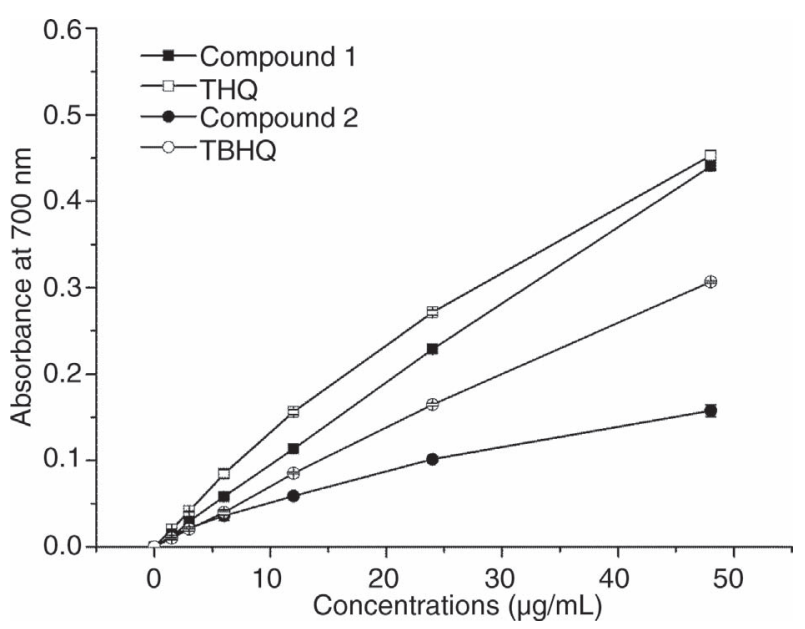

FIGURE 2. Reducing power of different antioxidants. Each value is expressed as mean \pm standard deviation $(n=3)$. 


\subsection{Reducing power}

The reducing powers of THQ, TBHQ and two newly synthesized compounds are shown in Figure 2. The reducing power of the four compounds increased significantly with increasing concentrations. At $48 \mu \mathrm{g} \cdot \mathrm{mL}^{-1}$, THQ and compound 1 showed moderate reducing powers of 0.45 and 0.44 , respectively, whereas the reducing powers of TBHQ and compound 2 were 0.31 and 0.16 , respectively. The $\mathrm{EC}_{50}$ values for the reducing power of THQ, TBHQ, compound 1 and 2 were 58.61, 98.57, 60.54 and $393.47 \mu \mathrm{g} \cdot \mathrm{mL}^{-1}$, respectively. The reducing power decreased as follows: THQ>compound $1>$ TBHQ $>$ compound 2. The Results show that methyl and tertbutyl substituents exert different degrees of influence on the electron-donating abilities of the compounds. The reducing power was also related to the phenolic hydroxyl group content in the samples investigated.

\section{ACKNOWLEDGMENTS}

The authors wish to thank Dr. H.M. Deng at the Instrumental Analysis and Research Center of Shanghai University for NMR spectra recording and the Shanghai Mass Spectrometry Center for HRMS analyses.

\section{REFERENCES}

Bauer RS, Dangayach KCB. 1992. Process for preparing lowchlorine epoxy resins. Patent No. US 5098964.

Hamama AA, Nawar WW. 1991. Thermal decomposition of some phenolic antioxidants. J. Agric. Food Chem. 39, 1063 1069. http://dx.doi.org/10.1021/jf00006a012.
Huang D, Ou B, Prior RL. 2005. The chemistry behind antioxidant capacity assays. J. Agric. Food Chem. 53, 1841-1856. http://dx.doi.org/10.1021/jf030723c.

Li JY, Wang T, Wu H, Ho CT, Weng XC. 2006. 1,1-Di-(2,5-dihydroxy-4-tertbutylphenyl)ethane: a novel antioxidant. J. Food Lipids 13, 331-340. http://dx.doi.org/10.1111/j.1745-4522. 2006.00056.x.

Li SMK. 1992. Process for preparing tetraphenolic compounds. Patent No. US 5146006.

Marmesat S, Morales A, Velasco J, Dobarganes MC. 2010. Action and fate of natural and synthetic antioxidants during frying. Grasas Aceites 61, 333-340. http://dx.doi. org/10.3989/gya.021910.

Molyneux P. 2004. The use of the stable free radical diphenylpicrylhydrazyl (DPPH) for estimating antioxidant activity. Songklanakarin J. Sci. Technol. 26, 211-219.

Oyaizu M. 1986. Studies on products of browning reactions: antioxidative activities of products of browning reaction prepared from glucosamine. Jpn. J. Nutr. 44, 307-315. http://dx.doi.org/10.5264/eiyogakuzashi.44.307.

Proestos C, Boziaris IS, Nychas GJE, Komaitis M. 2006. Analysis of flavonoids and phenolic acids in Greek aromatic plants: Investigation of their antioxidant capacity and antimicrobial activity. Food Chem. 95, 664-671. http:// dx.doi.org/10.1016/j.foodchem.2005.01.049.

Shahidi F, Zhong Y. 2010. Lipid oxidation and imroving the oxidative stability. Chem. Soc. Rev. 39, 4067-4079. http:// dx.doi.org/10.1039/b922183m.

Shimada K, Fujikawa K, Yahara K, Nakamura T. 1992. Antioxidative properties of xanthan on the autoxidation of soybean oil in cyclodextrin emulsion. J. Agric. Food Chem. 40, 945-948. http://dx.doi.org/10.1021/ jf00018a005.

Silva FAM, Borges F, Ferreira MA. 2001. Effects of phenolic propyl esters on the oxidative stability of refined sunflower oil. J. Agric. Food Chem. 49, 3936-3941. http://dx.doi. org/10.1021/jf010193p.

Tseng YH, Yang JH, Mau JL. 2008. Antioxidant properties of polysaccharides from Ganoderma tsugae. Food Chem. 107, 732-738. http://dx.doi.org/10.1016/j. foodchem.2007.08.073

Zhang CX, Wu H, Weng XC. 2004. Two novel synthetic antioxidants for deep frying oils. Food Chem. 84, 219-222. http:// dx.doi.org/10.1016/S0308-8146(03)00205-X. 